\title{
Studi Intervensi Kawasan Tanpa Rokok pada Tingkat Rumah Tangga
}

\author{
Interventional Study of Non-Smoking Area at Household Level
}

\author{
Najmah*, Fenny Etrawati**, Yeni***; Feranita Utama*
}

\begin{abstract}
*Departemen Epidemiologi FKM Universitas Sriwijaya, **Departeman Promosi Kesehatan FKM Universitas Sriwijaya, ***Departemen Biostatistika FKM Universitas Sriwijaya
\end{abstract}

\begin{abstract}
Abstrak
Perilaku merokok memberikan dampak negatif, baik bagi perokok aktif maupun pasif, ditinjau dari sudut pandang kesehatan maupun ekonomi. Regulasi mengenai Kawasan Tanpa Rokok (KTR) yang telah diterbitkan belum ada yang mengatur mengenai penerapan KTR di tingkat rumah tangga. Penelitian ini bertujuan untuk mengidentifikasi perubahan perilaku melalui intervensi terpadu KTR pada tingkat rumah tangga. Penelitian dilakukan pada bulan Juli - September 2014 menggunakan desain cluster trial pada empat desa di Kabupaten Ogan Ilir, Sumatera Selatan. Selanjutnya, 200 sampel kepala keluarga dipilih melalui metode cluster random sampling. Intervensi yang dilakukan meliputi konseling terpadu, pemberian permen pengganti rokok, dan tabungan sehat. Hasil penelitian menunjukkan bahwa proporsi responden yang merokok setiap hari dalam sebulan terakhir dan komitmen untuk tidak akan merokok di masa yang akan datang mencapai $71,6 \%$ dan $62 \%$ pada kelompok intervensi serta $91 \%$ dan $38 \%$ pada kelompok non-intervensi. Intervensi ini berpeluang $46 \%$ mengurangi perilaku merokok responden $(R R=0,46)$ setelah dikontrol oleh variabel pendidikan $(R R=0,152)$ dan sikap $(R R=0,216)$ dengan nilai $p<0,0001$. Intervensi terpadu ini terbukti berhasil mengubah perilaku merokok pada kawasan rumah tangga sehingga diperlukan partisipasi masyarakat dan dinas kesehatan setempat untuk menindaklanjuti penerapan intervensi ini dalam jangka panjang.
\end{abstract}

Kata kunci: Intervensi, kawasan tanpa rokok, perilaku, rumah tangga

\section{Abstract}

Smoking behavior has negative impacts, both for active and passive smokers, as reviewed from health and economic perspectives. Regulation concerning non-smoking area issued has not yet arranged implementation of non-smoking area at household level. This study aimed to identify any behavior change through integrated intervention of non-smoking area at household level. This study was conducted on July - September 2014 using cluster trial design in four villages at Ogan Ilir District, South Sumatra.
Then 200 household head samples were selected through cluster random sampling method. The intervention included integrated counseling, distribution of candy as substitute for cigarette, and healthy saving. Results of study showed that proportion of respondents who smoked every day in a recent month and had a commitment not to smoke in the future reached $71.6 \%$ and $62 \%$ in the intervention group, then $91 \%$ and $38 \%$ in the non-intervention group respectively. This intervention had $46 \%$ opportunity of reducing the smoking behavior of respondents $(R R=0.46)$ after controlled by education variable $(R R=0.152)$ and attitude $(R R=0.216)$ with $p$ value $<0.0001$. This integrated intervention was profoundly successful changing smoking behavior at household level. So that, public participation and health agency need to follow up the implementation of this intervention in a long term.

Keywords: Intervention, non-smoking area, behavior, household

\section{Pendahuluan}

Indonesia merupakan salah satu negara dengan tingkat konsumsi tembakau tertinggi di dunia. Hal ini terjawab melalui pelbagai catatan statistik yang menunjukkan tingginya jumlah perokok di Indonesia. Pada tahun 2004, diestimasikan bahwa sepertiga (34\%) dari orang Indonesia merokok. Melalui Riset Kesehatan Dasar Indonesia tahun 2008, diketahui bahwa $23,7 \%$ penduduk usia $>10$ tahun merokok setiap hari. ${ }^{1}$ Survei yang sama pada tahun 2010 menunjukkan bahwa $28,2 \%$ penduduk usia $>15$ tahun merokok setiap hari. Hasil ini menunjukkan adanya kenaikan yang signifikan persentase penduduk perokok aktif. Berdasarkan intensitasnya, seperlima dari jumlah perokok tersebut menghisap se-

Korespondensi: Najmah, Departemen Epidemiologi FKM Universitas Sriwijaya, Jl. Raya Palembang Prabumulih Gedung Dekanat Lantai 3 Ogan Ilir-Inderalaya 30662, No.Telp: 0711-580068 email: najem240783@yahoo.com 
banyak 11 - 20 batang (satu bungkus) rokok per hari. ${ }^{2}$ Perokok aktif tidak hanya didominasi oleh orang dewasa, persentase perokok pada remaja usia 13 - 15 tahun sebesar $12 \%$ dengan perbandingan perokok pada remaja putri dan remaja putra adalah $1: 12 .^{3}$ Lembaga statistik Indonesia pada periode 2001 - 2004 mencatat adanya lonjakan pada perokok pemula pada usia di bawah 10 tahun dari $0,4 \%$ naik menjadi $2,8 \% .{ }^{4}$ Hasil pencatatan tahun 2012 menunjukkan distribusi perilaku merokok masih tinggi dengan distribusi yang hampir sama berkisar $60 \%-80 \%$, baik pada penduduk di perkotaan maupun di pedesaan. Ironisnya, masyarakat dengan tingkat kekayaan pada kuintil terbawah yang paling banyak merokok. ${ }^{5}$

Pelbagai penyakit yang dapat dipicu melalui perilaku merokok antara lain infeksi saluran pernapasan akut (ISPA), pneumonia, dan tuberkulosis. Prevalensi nasional penyakit tersebut secara berturut adalah $8,10,0,63$, dan 0,40 . Jika dibandingkan dengan angka tersebut, Provinsi Sumatera Selatan memiliki prevalensi ISPA dan pneumonia di atas rata-rata nasional, yakni 10,08 dan 0,75. Sedangkan prevalensi tuberkulosis 0,15 lebih rendah dibandingkan dengan rerata kejadiannya di Indonesia. ${ }^{6}$ Ogan Ilir merupakan salah satu kabupaten di Sumatera Selatan dengan jumlah penduduk mencapai 400.000 jiwa. Hasil pencatatan kesehatan di Ogan Ilir menunjukkan bahwa ISPA merupakan penyakit dengan temuan kasus terbanyak, yakni 32.991. Sedangkan penderita tuberkulosis dengan pemeriksaan Basil Tahan Asam Positif (BTA+) sebanyak 343 kasus. $^{7}$

Perilaku merokok tidak hanya berdampak buruk bagi kesehatan kesehatan perokok aktif, tetapi juga terbukti memengaruhi status kesehatan perokok pasif. Pada tahun 2011, The Tobacco Atlas, ${ }^{8}$ mencatat bahwa setidaknya 600.000 perokok pasif meninggal dunia dan $75 \%$ di antaranya adalah perempuan dan anak-anak. Dalam rangka mengurangi besaran dampak akibat perilaku merokok, diperlukan suatu upaya inisiasi kawasan tanpa asap rokok tingkat rumah tangga di Ogan Ilir. Komposisi penduduk di daerah ini, yakni 29,3\% merupakan pelajar atau mahasiswa, diyakini rentan terhadap pengaruh perilaku merokok, baik aktif maupun pasif. Penerapan secara komprehensif model intervensi yang diadopsi dari Centers for Disease Controland Prevention (CDC) diharapkan dapat mengurangi dampak perilaku merokok di tingkat rumah tangga. Penelitian ini secara umum bertujuan untuk menguji efektivitas intervensi Kawasan Tanpa Rokok (KTR) pada tingkat rumah tangga di Ogan Ilir yang diadopsi dari CDC.

\section{Metode}

Penelitian ini merupakan riset kuantitatif dengan desain penelitian cluster experiment. Lokasi penelitian ini adalah di Kabupaten Ogan Ilir. Adapun populasi penelitian ini adalah seluruh rumah tangga di Kabupaten Ogan Ilir. Unit sampling adalah rumah tangga dan sampel penelitian adalah sebagian rumah tangga yang terdapat di Kabupaten Ogan Ilir. Sampel diambil dengan menggunakan teknik cluster random sampling.

Berdasarkan hasil acak, diperoleh empat desa yang menjadi lokasi penelitian, yaitu Desa Muara Penimbung Ilir, Desa Sungai Pinang, Desa Ulak Banding, dan Desa Tanjung Batu Seberang. Setelah desa terpilih, kemudian dilakukan pengacakan kembali untuk menentukan desa yang mendapat intervensi dan desa yang tidak mendapat intervensi. Berdasarkan hasil pengacakan, diperoleh desa yang akan mendapat intervensi adalah Desa Ulak Banding dan Desa Tanjung Batu Seberang. Sedangkan desa yang akan menjadi kontrol adalah Desa Muara Penimbung Ilir dan Desa Sungai Pinang.

Menurut Lemeshow, ${ }^{9}$ besar sampel minimal yang dibutuhkan dalam penelitian ini dihitung menggunakan rumus besar sampel untuk uji hipotesis beda dua rata-rata. Pada penelitian ini, diasumsikan perbedaan rata-rata skor perilaku merokok sebelum dan sesudah intervensi adalah $10 \%$ dengan varians $\left(\mathrm{s}^{2}\right)$ sebesar $5 \%$. Berdasarkan hasil perhitungan, diperoleh besar sampel minimal untuk satu kelompok adalah 40 responden. Untuk menghindari adanya loss to follow up atau sampel drop out, besar sampel minimal akan ditambah sebanyak $20 \%$ sehingga menjadi 48 responden. Besar sampel yang akan diambil pada tiap cluster digenapkan menjadi 50 responden per cluster (desa) sehingga total sampel yang diambil menjadi 200 responden. Tahap selanjutnya adalah pengambilan sampel pada tiap cluster yang dilakukan dengan teknik simple random sampling.

Kriteria inklusi pengambilan sampel untuk kelompok yang akan diintervensi dan kelompok kontrol yang tidak diintervensi yaitu responden adalah kepala keluarga, status telah menikah, dan status responden adalah perokok aktif. Tahapan penelitian yang dilakukan meliputi tiga tahapan penting, yaitu survei awal untuk melihat gambaran karakteristik rumah tangga, baik di desa intervensi maupun desa kontrol; intervensi program yang dilakukan selama satu bulan terhadap kepala rumah tangga terpilih dari desa intervensi, meliputi konseling terpadu tentang rokok yang diberikan oleh kader kesehatan yang telah dilatih, dan pemberian permen herbal pengganti rokok untuk mengurangi kebiasaan merokok dengan mengalokasikan sebagian uang rokok ke dalam celengan; posttest dilakukan melalui survei lapangan dalam rangka pengumpulan data kuantitatif pada kelompok intervensi dan non-intervensi. Analisis univariat meliputi variabel demografi (pekerjaan, status perkawinan, pendidikan, usia, jumlah anggota keluarga, dan jumlah balita di rumah) dan variabel perilaku merokok. Selanjutnya, analisis bivariat dilakukan dengan uji-t menggunakan alat 
bantu statistik untuk melihat perbedaan perilaku merokok antara kelompok intervensi dan kelompok nonintervensi. Regresi linear berganda dilakukan untuk tahap pemodelan akhir.

\section{Hasil}

Hasil analisis karakteristik demografi responden pada Tabel 1 menunjukkan bahwa mayoritas responden pada kelompok intervensi bekerja sebagai petani $(61 \%)$, sedangkan pada kelompok non-intervensi sebagian besar bekerja sebagai wiraswasta (44\%). Lebih dari 50\% responden pada kelompok intervensi tidak tamat sekolah dasar (SD) atau madrasah ibtidaiyah (MI) dan sebesar
34\% pada kelompok non-intervensi. Hasil analisis deskriptif terhadap karakteristik responden dapat dilihat pada Tabel 1. Rata-rata usia antara kelompok intervensi dan non-intervensi 46 tahun dan 44 tahun. Sedangkan jumlah anggota keluarga berkisar empat orang dan balita antara 0 - 2 balita per rumah pada kelompok intervensi dan non-intervensi.

Tabel 2 menunjukkan bahwa 84,2\% pada kelompok intervensi dan $67 \%$ pada kelompok non-intervensi tidak akan menolak rokok gratis yang diberikan. Sebanyak $65,3 \%$ pada kelompok intervensi tidak ingin merokok di masa yang akan datang dan $62 \%$ kelompok non-intervensi tetap akan merokok di masa yang akan datang.

Tabel 1. Gambaran Karakteristik Responden pada Desa Intervensi dan Non-Intervensi

\begin{tabular}{|c|c|c|c|c|c|}
\hline \multirow{2}{*}{ Variabel } & \multirow{2}{*}{ Kategori } & \multicolumn{2}{|c|}{ Intervensi $(\mathrm{n}=95)$} & \multicolumn{2}{|c|}{ Non Intervensi $(n=100)$} \\
\hline & & $\mathbf{n}$ & $\%$ & $\mathbf{n}$ & $\%$ \\
\hline \multirow[t]{7}{*}{ Pekerjaan } & Tidak kerja & 11 & 11,6 & 10 & 10 \\
\hline & TNI/POLRI & 1 & 1 & 1 & 1 \\
\hline & PNS/pegawai & 1 & 2 & 1 & 1 \\
\hline & Wiraswasta/jasa/dagang & 19 & 20 & 44 & 44 \\
\hline & Petani & 58 & 61,1 & 31 & 31 \\
\hline & Buruh & 4 & 4,2 & 9 & 9 \\
\hline & Lainnya & 0 & 0 & 4 & 4 \\
\hline \multirow[t]{4}{*}{ Status kawin } & Belum kawin & 0 & 0 & 7 & 7,5 \\
\hline & Kawin & 93 & 98,9 & 85 & 91,4 \\
\hline & Cerai hidup & 0 & 0 & 1 & 1,1 \\
\hline & Cerai mati & 1 & 1,1 & 0 & 0 \\
\hline \multirow[t]{7}{*}{ Pendidikan } & Tidak pernah sekolah & 9 & 9,5 & 3 & 3 \\
\hline & Tidak tamat SD/MI & 11 & 11,6 & 17 & 17 \\
\hline & Tamat SD/MI & 53 & 55,8 & 34 & 34 \\
\hline & Tamat SMP & 11 & 11,6 & 25 & 25 \\
\hline & Tamat SMA & 11 & 11,6 & 18 & 18 \\
\hline & Tamat D1/D2/D3 & 0 & 0 & 1 & 1 \\
\hline & Tamat PT & 0 & 0 & 2 & 2 \\
\hline \multicolumn{2}{|c|}{ Usia bapak (rata-rata) } & 46 & $(26-83)$ & 44 & $(27-69)$ \\
\hline \multirow{2}{*}{\multicolumn{2}{|c|}{$\begin{array}{l}\text { Jumlah anggota keluarga (rata-rata) } \\
\text { Jumlah balita (rata-rata) }\end{array}$}} & 4 & $(1-8)$ & 4 & $(1-8)$ \\
\hline & & 0 & $(0-2)$ & 1 & $(0-2)$ \\
\hline
\end{tabular}

Tabel 2. Gambaran Perilaku Merokok Responden pada Desa Intervensi dan Non-Intervensi

\begin{tabular}{|c|c|c|c|c|c|c|c|c|}
\hline \multirow{3}{*}{ Perilaku } & \multicolumn{4}{|c|}{ Intervensi $(\mathbf{n}=95)$} & \multicolumn{4}{|c|}{ Non Intervensi $(n=100)$} \\
\hline & \multicolumn{2}{|c|}{ Ya } & \multicolumn{2}{|c|}{ Tidak } & \multicolumn{2}{|c|}{ Ya } & \multicolumn{2}{|c|}{ Tidak } \\
\hline & $\mathbf{n}$ & $\%$ & $\mathbf{n}$ & $\%$ & $\mathbf{n}$ & $\%$ & $\mathbf{n}$ & $\%$ \\
\hline Pernah menolak rokok gratis & 80 & 84,2 & 15 & 15,8 & 67 & 67 & 33 & 33 \\
\hline & \multicolumn{7}{|c|}{ Merokok sebulan terakhir } & 38 \\
\hline Ya, setiap hari & 68 & 71,6 & 27 & 28,4 & 91 & 91 & 9 & 9 \\
\hline Ya, kadang-kadang & 22 & 23,2 & 73 & 76,8 & 8 & 8 & 92 & 92 \\
\hline Tidak, tapi sebelumnya pernah & 4 & 4,2 & 91 & 95,8 & 0 & 0 & 100 & 100 \\
\hline Tidak pernah sama sekali & 1 & 1,1 & 91 & 98,9 & 1 & 1 & 99 & 99 \\
\hline \multicolumn{9}{|l|}{ Merokok di rumah } \\
\hline Di dalam rumah & 56 & 58,9 & 39 & 41 & 70 & 70 & 30 & 30 \\
\hline Di depan rumah & 10 & 10,5 & 85 & 89,5 & 16 & 16 & 84 & 84 \\
\hline Di luar pekarangan rumah & 29 & 30,5 & 66 & 69,5 & 14 & 14 & 86 & 86 \\
\hline Merokok dengan anggota keluarga & 26 & 27,4 & 69 & 72,6 & 70 & 70 & 30 & 30 \\
\hline Mengajak orang lain merokok & 19 & 20 & 76 & 80 & 43 & 43 & 57 & 57 \\
\hline Mengajak orang lain tidak merokok & 36 & 37,9 & 59 & 62,1 & 48 & 48 & 52 & 52 \\
\hline Keinginan untuk berhenti merokok & 89 & 100 & 6 & 6,3 & 80 & 86,7 & 20 & 20 \\
\hline
\end{tabular}


Tabel 3. Riwayat Merokok Responden pada Desa Intervensi dan Non-Intervensi

\begin{tabular}{lcc}
\hline Variabel & Intervensi $\mathbf{( n = 9 5 )}$ & Non-Intervensi $(\mathbf{n}=\mathbf{1 0 0})$ \\
\hline Usia pertama kali merokok (rata-rata/median) & $15.50(5-53)$ & $15(6-35)$ \\
Usia pertama kali merokok tiap hari (rata-rata/median) & $19(7-60)$ & $18(6-40)$ \\
Rata-rata batang rokok per hari(rata-rata/median) & $12(1-48)$ & $12(1-80)$ \\
Usia berhenti merokok (rata-rata/SD) & $50(12,2)$ & $48(11,24)$ \\
\hline
\end{tabular}

Tabel 4. Perbedaan Perilaku Merokok Responden pada Desa Intervensi dan Non-Intervensi

\begin{tabular}{lccccc}
\hline Variabel & $\begin{array}{c}\text { Rata-rata } \\
\text { Intervensi }(\mathbf{n}=\mathbf{9 5})\end{array}$ & $\begin{array}{c}\text { Rata-rata } \\
\text { Non Intervensi }(\mathbf{n}=\mathbf{1 0 0})\end{array}$ & $\begin{array}{c}\text { Beda } \\
\text { Rata-rata }\end{array}$ & Nilai $\mathbf{p}$ & $\mathbf{9 5 \%} \mathbf{C I}$ \\
\hline Perilaku & 7,40 & 5,75 & $-1,650$ & 0,0001 & $-2,141-1,159$ \\
\hline
\end{tabular}

Tabel 5. Rasio Risiko Perilaku Merokok setelah Dikontrol oleh Variabel Perancu

\begin{tabular}{lll}
\hline \multirow{2}{*}{ Variabel } & \multicolumn{2}{c}{ Risk Ratio } \\
\cline { 2 - 3 } & Crude $\mathbf{R R}$ & Adjusted RR$^{*}$ \\
\hline Intervensi & $* 0,462$ & $* 0,463$ \\
Pendidikan & 0,131 & $* 0,152$ \\
Pekerjaan & $-0,064$ & - \\
Usia (tahun) & $-0,071$ & - \\
Skor sikap & $* 0,227$ & $* 0,216$ \\
Skor pengetahuan & $-0,052$ & - \\
\hline
\end{tabular}

*dikontrol oleh tingkat pendidikan dan sikap, nilai $\mathrm{p}<0,005$

Sedangkan proporsi responden yang merokok setiap hari dalam sebulan terakhir mencapai 71,6\% pada kelompok intervensi dan $91 \%$ pada kelompok non-intervensi. Selain itu, 58,9\% kelompok intervensi merokok di dalam rumah dan $72,6 \%$ responden tidak merokok dengan anggota keluarga. Sedangkan pada kelompok non-intervensi diketahui bahwa $70 \%$ responden merokok di dalam rumah dan bersama anggota keluarga.

Berdasarkan Tabel 3 diketahui karakteristik perilaku merokok pada kelompok intervensi dan non-intervensi hampir sama. Rata-rata usia pertama kali merokok adalah 15 tahun pada kedua kelompok dan rata-rata merokok tiap hari pada saat responden usia 19 tahun pada kelompok intervensi serta usia 18 tahun pada kelompok non-intervensi. Rata-rata jumlah rokok tiap hari mencapai 20 batang, sedangkan usia berhenti merokok pada usia 50 tahun pada kedua kelompok.

Perbedaan perilaku antara kelompok intervensi dan non-intervensi dapat dilihat pada Tabel 4. Hasil analisis menunjukkan bahwa rata-rata skor perilaku merokok kelompok intervensi mencapai 7,40 dan 5,75 pada kelompok non-intervensi $(-2,141$ - 1,159). Hasil uji statistik menunjukkan bahwa nilai $\mathrm{p}<5 \%$. Ada perbedaan yang bermakna antara perilaku merokok pada kelompok intervensi dan perilaku merokok pada kelompok pada kelompok non-intervensi.

Hasil analisis pada Tabel 5 menunjukkan bahwa secara bersama-sama variabel intervensi berpengaruh sig- nifikan terhadap perubahan perilaku responden (nilai $\mathrm{p}$ $<0,05)$. Hasil intervensi yang dilakukan memiliki peluang $46 \%$ untuk mengurangi perilaku merokok responden $(R R=0,46)$ setelah dikontrol oleh variabel pendidikan $(R R=0,152)$ dan sikap $(R R=0,216)$.

\section{Pembahasan}

Umumnya, perokok berasal dari pelbagai latar belakang pekerjaan. Namun, dalam penelitian ini paling banyak bekerja sebagai petani, wiraswasta, dan tidak bekerja, baik untuk kelompok intervensi maupun untuk kelompok non-intervensi. Kecenderungan merokok, baik pada kelompok intervensi maupun non-intervensi, tidak hanya terjadi pada kelompok responden yang bekerja, tetapi juga pada kelompok responden yang tidak bekerja. Kedua kategori tersebut berkaitan dengan tingkat stres pada pekerja atau pengangguran dengan menjadikan rokok sebagai media untuk mengurangi stres. ${ }^{10}$ Posisi pekerjaan seseorang akan berdampak terhadap besar kecilnya penghasilannya. Harga rokok yang cukup mahal seharusnya menjadi hambatan bagi mereka yang berpenghasilan rendah untuk merokok. Faktanya, di Indonesia justru perokok aktif banyak berasal dari masyarakat dengan tingkat kekayaan pada kuintil terbawah dengan distribusi $60 \%-80 \%$, dari jumlah penduduk, baik di perdesaan maupun di perkotaan. ${ }^{2}$ Pada keluarga kurang mampu, persentase pengeluaran rumah tangga untuk rokok bahkan lebih besar lagi. ${ }^{11}$

Status sebagai kepala keluarga yang penuh dengan tanggup jawab terhadap anggota keluarganya sering menjerumuskan seseorang ke dalam kebiasaan merokok. Akan tetapi, status perkawinan seseorang tidak hanya membawa risiko ke arah perilaku merokok pada laki-la$\mathrm{ki}$, tetapi juga dapat digunakan sebagai peluang untuk melakukan intervensi bidang kesehatan dalam menurunkan perilaku merokok. Laki-laki yang lajang cenderung meneruskan perilaku merokok, sedangkan lakilaki yang menikah berhasil berhenti merokok. ${ }^{12}$ Dengan demikian, dapat disimpulkan bahwa mereka yang menikah relatif lebih sukses dalam program berhenti 
merokok dengan adanya perubahan struktur keluarga yang semula lajang kemudian beristri dan estimasi adanya dukungan dari pasangannya untuk mendukung program berhenti merokok.

Lebih dari 50\% responden penelitian di Ogan Ilir ini, baik pada kelompok yang diintervensi maupun yang tidak diintervensi, hanya mengenyam kategori pendidikan dasar, baik tamat maupun tidak tamat SD. Hal ini senada dengan hasil penelitian Reimondos et al, ${ }^{5}$ yang mencatat lebih dari $60 \%$ perokok aktif berpendidikan rendah. Hal ini sungguh ironis, masyarakat terkategori sosial ekonomi rendah justru lebih banyak menghabiskan penghasilannya untuk rokok daripada untuk keperluan pendidikan dan kesehatan. Pendidikan seseorang secara alamiah seharusnya berpengaruh terhadap tingkat pengetahuan seseorang. Akan tetapi, tidak semua institusi pendidikan memberikan mata ajar yang spesifik mengenai dampak buruk yang dapat ditimbulkan karena perilaku merokok. Oleh karena itu, di masyarakat dapat juga ditemui fenomena bahwa mereka yang tingkat pendidikannya tinggi tetap berperilaku merokok sehingga tidak terdapat korelasi di antara keduanya. ${ }^{13} \mathrm{Hal}$ ini dimungkinkan karena ketidakterpaparan dengan informasi tentang rokok, didukung dengan kondisi lingkungan (peer group) yang tidak merokok membuat seorang individu terproteksi untuk tidak ikut mencoba rokok. Selain itu, tingkat pendidikan orangtua secara statistik menjadi faktor prediktor bagi perilaku merokok anak remajanya. ${ }^{14,15} \mathrm{Hal}$ ini dikarenakan remaja cenderung akan melakukan perilaku yang sama dengan panutannya, termasuk orangtua. ${ }^{16}$

Kebiasaan merokok merupakan masalah kesehatan yang cukup sulit diselesaikan. Salah satu upaya yang dapat dilakukan adalah dengan menerapkan peraturan tentang KTR seperti yang diatur dalam undang-undang. Komitmen dari pemangku kepentingan melalui penerapan sanksi yang tegas terhadap perokok di tempat kerja dan institusi pendidikan serta larangan iklan rokok terbukti memberikan dampak positif terhadap penurunan perilaku merokok masyarakat. ${ }^{17}$ Selain itu, komitmen untuk mengubah perilaku juga harus timbul dari dalam diri warga masyarakat di segala tatanan. Salah satu contoh, penerapan kebijakan kampus bebas dari asap rokok secara signifikan $(6 \%-12 \%)$ mengurangi kebiasaan merokok, sekaligus menjadi media promosi kesehatan untuk menghentikan perilaku merokok mahasiswa Fakultas Kedokteran Universitas Gadjah Mada. ${ }^{18}$

Penerapan KTR di institusi pendidikan dan tempat kerja relatif lebih mudah untuk ditegakkan sekaligus diawasi dibandingkan dengan masyarakat di luar institusi pendidikan dan tempat kerja. Bahkan, peraturan KTR yang ada belum mencantumkan pembentukan KTR di level rumah tangga. Hasil penelitian ini membuktikan bahwa sebanyak $70 \%$ responden pada kelompok non-in- tervensi merokok di dalam rumah atau di hadapan anggota keluarganya bahkan 62\% menyatakan akan tetap merokok. Ketidaktahuan akan bahaya merokok akan berlanjut pada pembentukan sikap dan perilaku terkait konsumsi rokok. Hal ini sejalan dengan penelitian yang dilakukan di Victoria, Australia, para orangtua percaya bahwa asap rokok sangat berbahaya bagi balita mereka. Walaupun hanya satu per lima orangtua yang menerapkan KTR di rumah tangga, KTR secara signifikan berhubungan dengan pengurangan rasio urinary cotinine dan creatinine pada balita. ${ }^{19}$ Penelitian lain di Nigeria menunjukkan bahwa $88 \%$ responden menyadari bahaya rokok. Tingkat kesadaran tersebut berhubungan secara signifikan dengan karakteristik sosiodemografi, riwayat merokok sebelumnya, paparan asap rokok di rumah dan tempat umum serta persepsi terhadap penggunaan tembakau itu sendiri. ${ }^{20}$

Perwujudan KTR dapat dimulai dengan melakukan pelbagai intervensi di masyarakat. Intervensi untuk berhenti merokok dapat dilakukan ketika masyarakat terkena dampak akibat rokok, misalnya pelaksanaan konseling spesifik oleh dokter gigi bahwa terdapat keterkaitan antara perilaku merokok dan penyakit pada gusi walaupun secara umum pasien mengetahui dampak umum akibat merokok adalah kerusakan paru-paru. ${ }^{21}$ Keberhasilan program berhenti merokok pada pasien tergantung dari besar kecilnya ketertarikan mereka untuk berpartisipasi aktif dalam program tersebut. Analisis terhadap data yang dikumpulkan National Cancer Institute menunjukkan bahwa $62,8 \%$ tertarik untuk mengikuti pelbagai terapi perubahan perilaku merokok, sedangkan $75 \%$ responden menginginkan terapi obat untuk sembuh dari penyakitnya. ${ }^{22}$ Upaya terbaik yang dapat dilakukan untuk mewujudkan KTR adalah promosi kesehatan yang bersumber daya masyarakat (dibantu oleh kader terlatih) sebelum timbul dan parahnya penyakit yang diakibatkan perilaku merokok. Meskipun demikian, dukungan kelompok merupakan hal yang dinilai lebih berimplikasi terhadap pengurangan perilaku merokok dibandingkan dengan format lain, termasuk video pendidikan, informasi tertulis atau bahkan konseling oleh kader. ${ }^{23}$

Upaya pencegahan primer melalui konseling saja tidak cukup. Kelompok intervensi dalam penelitian ini diberikan permen sebagai pengganti rokok. Perbedaan perilaku merokok tampak nyata pada kedua kelompok, yakni dengan besar perbedaan skor perilaku $=2$ (nilai $\mathrm{p}$ $<0,05)$. Penggunaan produk pengganti tembakau (nikotin) telah terbukti menurunkan perilaku merokok partisipan, baik pada kelompok yang memiliki motivasi dan tingkat depresi yang tinggi maupun rendah. Walaupun demikian, hasilnya akan lebih baik jika responden memiliki motivasi yang kuat untuk berhenti merokok dan menghilangkan depresi. Dalam konsep psikologis, konsumsi produk pengganti tembakau ini 
merupakan salah satu bentuk coping terhadap stres. ${ }^{24}$

\section{Kesimpulan}

Mayoritas kelompok intervensi tidak ingin merokok di masa yang akan datang dan proporsi responden yang merokok setiap hari dalam sebulan terakhir lebih rendah $20 \%$ dibandingkan pada kelompok non-intervensi. Selain itu, proporsi kelompok intervensi merokok di dalam rumah lebih tinggi dibandingkan kelompok nonintervensi. Intervensi berupa konseling terpadu, pemberian permen pengganti rokok, dan pesan singkat sehat memberikan pengaruh yang signifikan terhadap perubahan perilaku responden setelah dikontrol dengan variabel pendidikan dan sikap. Intervensi ini memberikan peluang $46 \%$ untuk mengurangi perilaku merokok. Hasil pengukuran menunjukkan angka merokok di dalam rumah 14\% lebih rendah pada kelompok intervensi dibandingkan dengan kelompok non-intervensi. Hal ini mengindikasikan partisipasi masyarakat yang cukup baik untuk mewujudkan KTR pada tingkat rumah tangga.

\section{Saran}

Penelitian ini merekomendasikan untuk mengedukasi kepala keluarga dalam rangka kesehatan melalui kegiatan konseling terpadu yang membahas isu seputar perilaku merokok, pemberdayaan kader kesehatan dalam mewujudkan lingkungan rumah tangga tanpa asap rokok dan meningkatkan kesadaran tentang bahaya merokok di masa yang akan datang, tidak hanya untuk kepala keluarga yang merokok, tetapi juga anggota keluarga yang tinggal dalam satu rumah cukup efektif mengurangi perilaku merokok pada tingkat rumah tangga. Penelitian selanjutnya diharapkan dapat dilakukan intervensi lebih lama dan dapat dilakukan aplikasi intervensi terpadu pada skala tempat lainnya, seperti kawasan belajar-mengajar, pelayanan kesehatan, transportasi.

\section{Ucapan Terima Kasih}

Kami mengucapkan terima kasih kepada Lembaga Penelitian Universitas Sriwijaya yang telah mendukung pelaksanaan kegiatan ini melalui dana DIPA Universitas Sriwijaya Nomor 023-04.2.415112/2014 tanggal 5 Desember 2013. Terima kasih juga kami ucapkan kepada para peserta intervensi di Kabupaten Ogan ilir dan para asisten peneliti dalam menyukseskan penelitan ini.

\section{Daftar Pustaka}

1. Republic of Indonesia Ministry of Health. The tobacco source book: data to support nasional tobacco control strategy. Jakarta: Indonesia Ministry of Health; 2004.

2. Badan Pusat Statistik. Survey demografi dan kesehatan Indonesia. Jakarta: Badan Pusat Statistik; 2012.

3. Kementerian Kesehatan Republik Indonesia. Riset kesehatan dasar tahun 2007. Jakarta: Kementerian Kesehatan Republik Indonesia; 2008.
4. Kementerian Kesehatan Republik Indonesia. Riset kesehatan dasar tahun 2010. Jakarta: Kementerian Kesehatan Republik Indonesia; 2010.

5. Global Youth Tobacco Survey (GYTS). Indonesia-nasional 2006. Atlanta-USA: Centers for Disease Control and Prevention (CDC); 2009.

6. Dinas Kesehatan Kabupaten Ogan Ilir. Profil kesehatan Kabupaten Ogan Ilir tahun 2009. Indralaya: Dinas Kesehatan Kabupaten Ogan Ilir; 2009.

7. Dinas Kesehatan Provinsi Sumatera Selatan. Ringkasan eksekutif data dan informasi kesehatan Provinsi Sumatera Selatan. Palembang: Dinas Kesehatan Provinsi Sumatera Selatan; 2012.

8. Eriksen M, Hana R dan Judith M. The tobacco atlas, $4^{\text {th }}$ edition. AtlantaGeogia: American Cancer Society; 2011.

9. Lemeshow S, Hosmer DW dan Klar J. Besar sampel dalam penelitian kesehatan. Dalam: Pramoni D, Kusnanto H, editor. Yogyakarta: Gadjah Mada University Press; 1997.

10. Perkins KA, Giedgowd GE, Karelitz JL, Conklin CA dan Parzyns CS. Expectancy for negative affect relief due to smoking may not be predictive under acute mood situations. Experimental and Clinical Psychopharmacology. 2012; 20 (2): 161-6.

11. Reimondos A, Utomo ID, McDonald P, Hull T, SuparnoH, dan Utomo A. Merokok dan penduduk dewasa muda di Indonesia, the 2010 Greater Jakarta Transition to Adulthood Survey-Policy Background No. 2. Canberra: Australian Demographic and Social Research Institute -the Australian National University ; 2012.

12. Broms U, Silventoinen K, Lahelma E, Koskenvuo M, Kaprio J. Smoking cessation by socioeconomic status and marital status: the contribution of smoking behavior and family background. Oxford Journals. 2004; 6 (3): 447-55.

13. Chotidjah S. Pengetahuan tentang rokok, pusat kendali kesehatan eksternal dan perilaku merokok. Makara Seri Sosial Humanioral. 2012; 16 (1): 49-56.

14. Berg C J, An LC, Thomas JL, Lusi KA, Sarem JR, Swam PW, et.al. Smoking patterns, attitudes and motives: unique characteristics among 2-year versus 4-year college students. Health Education Research. 2011; 26 (4): 614-23.

15. Vries, Hd, Engels R, Kremers S, Wetzels J, Mudde A. Parents' and friends' smoking status as predictors of smoking onset: findings from six European countries. Health Education Research. 2003;18 (5): 627-36.

16. Septiono W, Meyrowitsch DW. Family role towards smoking behavior among children in Jakarta. Kesmas: Jurnal Kesehatan Masyarakat Nasional. 2014; 9 (1): 58-63.

17. Azkha N. Studi efektivitas penerapan kebijakan perda kota tentang kawasan tanpa rokok (ktr) dalam upaya menurunkan perokok aktif di Sumatera Barat tahun 2013. Jurnal Kebijakan Kesehatan Indonesia, 2013; 2 (4): 171-9.

18. Prabandari YS, Ng N, Padmawati RS. Kawasan tanpa rokok sebagai alternatif pengendalian tembakau studi efektivitas penerapan kebijakan kampus bebas rokok terhadap perilaku dan status merokok mahasiswa di fakultas kedokteran UGM, Yogyakarta. Jurnal Manajemen Pelayanan Kesehatan. 2009; 12 (4): 218-25.

19. Blackburn C, Spencer N, Bonas S, Coe C, Dolan A, Moy R. Effect of strategies to reduce exposure of infants to environmental tobacco smoke in the home: cross sectional survey. British Medical Journal. 2003; 327 (1): 257-61. 
20. Onyeonoro UU, Chukwuonye II, Madukwe OO, Ukegbu AU, Akhimien MO Ogah OS. Awareness and perception of harmful effects of smoking in Abia State, Nigeria. Nigerian Journal of Cardiology. 2015; 12 (1): $27-$ 33.

21. Terrades M, Coulter WA, Clarke H, Mullally BH, Stevenson M. Patients' knowledge and views about the effects of smoking on their mouths and the involvement of their dentists in smoking cessation activities. British Dental Journal. 2009; 207 (E22): 1-6.

22. Berg CJ, Carpenter MJ, Jardin B, Ostroff JS. Harm reduction and cessa- tion efforts and interest in cessation resources among survivors of smoking-related cancers. Journal of Cancer Survivorship. 2013; 7 (1): 44-54.

23. Dietz NA, Hooper MW, Byrne M, Messiah A, Baker EA, Parker DF, et al. Developing a smoking cessation intervention within a communitybased participatory research framework. Journal of Smoking Cessation. 2012; 7 (2): 89-95.

24. Carpenter MJ, Alberg AJ, Graya KM, Saladin ME. Motivating the unmotivated for health behavior change: a randomized trial of cessation induction for smokers. Clinical Trials. 2010; 7 (1): 157-66. 